\title{
Identifying Similar Mystical Experience within Literature
}

\author{
Karen Kuhn \\ Department of Dutch and South African Studies, Faculty of English \\ Adam Mickiewicz University of Poznań, Poland
}

\begin{abstract}
Johanna Brandt (1876-1964) was a South African propagandist, spy, writer and prophet. She played a big role in both Afrikaner nationalism and the Anglo-Boer War. Brandt wrote several books including: The Petticoat Commando (1913) and The Grape Cure (1927). Her religious views in her books: The Millennium - A Prophetic Message to the Native Tribes of South Africa (1918) and The Paraclete or Coming World Mother (1939) reflect visions and imagery of the supernatural in Afrikaans literature. The study is part of a Ph.D. focusing on Carl Jung's; The Red Book or Liber Novus (written between 1913 and 1930, published in 2009) as key to the interpretation of the synchronicity within the dialogue of female mystical texts between (1918 - 1939). This study specifically focuses on the similarities between the French mystic; Simone Weil (1909 - 1943) and Johanna Brandt. By looking at these texts within diverse religions, geographies and cultures, with Jung's theory as interpretation, literature serves as a tool to identify similar mystical experiences.
\end{abstract}

Keywords: Mysticism, Johanna Brandt, Simone Weil, C.G. Jung

Die Mystiek is wetenskappelike Kennis van Eeuwige Waarhede. Mysticism is scientific Knowledge of Eternal Truths. [1]

\section{Introduction}

On the night of the first of December 1916 while guarding her mother's deathbed, Johanna Brandt had a mystical experience. She recorded the mystical encounter and accompanied religious views, visions and imagery in her books: The Millennium - A Prophetic Message to the Native Tribes of South Africa (1918) and The Paraclete or Coming World Mother (1939). No publisher was willing to publish The Millennium and she did it at her own expense. The publication caused an outcry in both religious and political circles. Brandt recorded that all the newspapers in South Africa (Unioniste, S.A.P en Nationaliste) attacked, ridiculed and derided her.[2]

The study of plasing Brandt's work in conversation with other contemporary female mystics, aims to shed a different light on these marginalized texts of Brandt. The intention is not the comparison or questioning of the impact, influence or dynamism of the writers.

\section{Mysticism}

Mysticism is a term deriving from the Greek; $\mu \nu \omega$ meaning; 'I conceal' and as a collective finds itself seated in a variety of dissiplines altering across the ages. A transformation established within an individual due to a personal experience of some form of contact with a deity, a higher source from a different time-space reality, regardless of the religious context. The hermeneutics of these texts are done within the Swiss psychoanalyst Carl Gustav Jung's theoretical framework. Jung believed that the transformation of the self is at the mystical core of all religions.

Jung refers to the participation mystique:

[...] which is nothing but a relic of the original non-differentiation of subject and object, and hence of the primordial unconscious state.[1]

He further mentions: "The "mystical" experience of the French philosopher Descartes involved a ... sudden revelation in which he saw in a flash the "order of all sciences" [4]

Science became a dominant feature within the nineteenth century mysticism discourse, ensuring a lot of criticism. Jung describes his own mystical encounter as a 'Mystical Marriage', the alchemical transformation of 
opposing forces in harmony. Yet another complex notion; the unification of the paradox, present in a vast amount of works ranging from Alchemy, the Kabbalah, Taoism, to name but a few.

Similarities are drawn in the texts of Brandt and Weil in terms of; a calling, physical and mental experience, a medium and the message.

\section{Johanna Brand}

Johanna van Warmelo was born on the $18^{\text {th }}$ of November 1876 in Heidelberg, in the Transvaal (a province from 1910-1976) in South Africa. She grew up in a parsonage, within the Dutch Reform Church. Her father emigrated from the Netherlands and this established a link to Europe for Johanna. Her mother descended from a family of Afrikaner pioneers which in their turn fostered a strong sense of patriotism within Johanna.

After her father's death Johanna and her mother moved to the Harmonie estate, on the banks of the Apiesriver in Sunnyside, Pretoria. In 1897 Johanna and her mother embarked on a six months trip to Europe. With the outbreak of the Anglo-Boer War in 1899, Johanna worked as a nurse in the Irene-concentration camp up till when the British subjugated Pretoria. Lord Kitchener's headquarters was situated near Harmonie, resulting in the estate becoming the center of British occupation. It is during these times that Johanna and her mother started a secret service that served as link for personal relations between the Boer force and (president) Paul Kruger in The Netherlands. Johanna also objected the poor conditions within the camps and later published two books: Het concentratie-kamp van Iréne (1904) and Die Kappie Kommando (1913) The Petticoat Commando or Boer Women In Secret Service (1913) a reportage of the dire conditions within the camps. Johanna married Louis Ernst Brandt in the Netherlands. He emigrated to South Africa where he served 21 years as moderator of the Dutch Reformed Church.[5]

\section{Simone Weil}

The French philosopher, activist, and mystic, Simone Weil (1909-1943) was described by Albert Camus as "the only great spirit of our time." Born in Paris, in Weil's brief 34 years, she left a legacy behind as a saint. Born as a Jew, Weil resonated towards Catholicism but yet refused to get baptized in order to remain outside the Church and independent. Weil grew up in a loving home, her brother André Weil became one of the most influential mathematicians of the twentieth century. Most of Weil's spiritual work was published posthumous and will be the focus, taken into account the diverse roles; teacher, labor activist, intellectual, resistance fighter and academic amongst others that Weil fulfilled and thus her writings as an aggregate.[6]

Weil was deeply moved by George Herbert's poem Love bade me welcome, "le Christ lui-même est descendu et m'a prise". In 1938 Weil reported that during one of these recitations: "Christ himself came down and took possession of me." [7]

\section{Similarities}

\subsection{The Calling}

Both Brandt and Weil testifies that the mystical experience occurred unexpected and unwanted.

Toe kreeg ik die grote skok van mijn lewe.

Onverwagt, ongesogt, selfs ongewenst was dit toe dit kwam - die Goddelike Skok wat die wereld van Mystiek ontsluit, terwijl dit die

ware betekenis van die wereld van Materie aan die lig breng.

I got the biggest shock of my life.

Unexpected, unwanted and undesirable when it came - the Godly Shock that unlocks the world of Mysticism, whilst it is shedding light on the true meaning of the world of Matter. [8]

Here Brandt supports the notion of Science within Mysticism.

Weil confesses: 
God in his mercy had prevented me from reading the mystics, so that it should be evident to me that I had not invented this absolutely unexpected contact. [9]

Present in both texts the notion of a calling. In urgency an invitation is posed to the writer as a duty from a deity; to embrace solitude and withdraw from reality. A concept denoting from the beginning of Saint John of the Cross' poem; 'The Dark night of the Soul": [...] / My house being now at rest. / [...]. [10] Weil testified that the works of Saint John of the Cross had a great impact on her. This concept is also present in the renowned Jungian Scholar Joseph Campbell's: The Hero's Journey, where the call to adventure at the beginning of the narrative forms part of the Monomyth.[11]

Brandt writes:

Trek u van die wereld vir een tijdje terug, en ga dan uit en gebruik hierdie ervaring sonder voorbehoud tot die opheffing van uw medemens"

Dit was die bevel van die Boodskapper.

Withdraw yourself from this world for a while, and then go out and use this experience, without reservation, to the edification of your fellowmen.

That was the Messenger's command. [12]

Weil writes;

I feel that it is necessary to me, prescribed for me, to be alone, an outsider and alienated from every human context whatsoever. [13]

Having so intense and so painful a sense of this urgency, I should betray the truth, that is to say the aspect of truth that I see, if I left the point, where I have been since my birth, at the intersection of Christianity and everything that is not Christianity. [14]

\subsection{Physical and Mental Experience}

The Millennium - A Prophetic Message to the Native Tribes of South Africa (1918) and The Paraclete or Coming World Mother (1939) contains personal inscriptions by Brandt on the first of December 1916 regarding her experience in both mental and physical states. Mystical texts all testify the physical and emotional suffering and bliss experienced during a mystical encounter. Ranging from immolation, mortification, stigmata to physical illness and pain as well as feelings of climatic ecstasy and pure bliss. Both Brandt and Weil noted that this experience was not self-induced, or that they found themselves in a state of powerlessness incapable of cognitive and non-cognitive functioning .

Met verpletterende skielikheid kwam dit, en vervoerde mij naar die betowerende sfere van die gees, terwijl ik in die volle besit bleef van die vermogens van verstand en liggaam.

And with crushing suddenness it came, and carried me to the magical spheres of the soul, while I remained in full possession of the abilities of mind and body. [15]

While describing the paradoxical nature of her experience, Weil mentions her sobriety;

Moreover, in this sudden possession of me by Christ, neither my senses nor my imagination had any part; [..]. [16]

Brandt gives extensive descriptions of her physical suffering that she endured:

Van die liggamelike uitputting van die volgende dage, die swve tusse dood en lewe wat so kritiek is wanneer die gees geen weerstand bied, kan ik geen rekenskap gee nie. Passief-gehoorsaam, liet ik mij versorg, dag en nag.

I can not account for the physical exhaustion during the following days, drifting between life and death, which is so crucial when the spirit shows no resistance. Passive-obedient I allowed myself to be taken care of. [17]

Together with the pain, Brandt mentions the exhilaration:

Een-en-twintig uur het dit geduur, en elk een daarvan is in die geheue ingegrif soos een juweel van verblindende heerlikheid 
Twenty one hours it lasted, and each one of them ingrained in the memory like a jewel of blinding glory. [18]

Since childhood Brand had poor health and at the age of forty she was diagnosed with stomach cancer. She refused medical treatment and followed a special diet consisting of water, milk and fruit. Johanna healed completely and died 23 January 1964 at the age of 87 in her apartment in Newlands, Cape Town. Brandt also wrote the following two books; The grape cure (1927) en The Fasting-Book: a book on the creation and redemption of the body (1921), which deals with alternative methods of healing. [19]

Weil battled her whole life with pounding headaches, sinusitis and frail health in general. She frequently refers to illness and suffering within her works and her social activism contributed to her deterioration. Weil died at the young age of thirty-four.

I only felt in the midst of my suffering the presence of love, like that which one can read in the smile on a beloved face. [20]

\subsection{A Medium}

Initially Brandt records that during her mystical experience she engaged with an angel, a messenger and in her book; The Paraclete or Coming World Mother (1939) as the Holy Ghost in the form of The Paraclete, the World Mother.

The Comforter, Which is the Holy Ghost, Whom the Father will send in My Name, She shall teach you all things, and bring all things to your remembrance, whatsoever I have said unto you. [21]

Weil's writes:

Sometimes, also, during this recitation or at other moments, Christ is present with me in person, but his presence is infinitely more real, more moving, more clear than on that first occasion when he took possession of me. [22]

\subsection{Message}

As mentioned the teachings within Simone Weil's aggregate oeuvre stretches far beyond the focus of this essay. Certain similarities were drawn from her religious writing, that is in correlation with Johanna Brandt's message. A central message of unification with the Divine is present in these writings. Weil gives testimony of the this concept of the 'mystical marriage':

For our true dignity is not to be parts of a body, even though it be a mystical one, even though it be that of Christ. It consists in this, that in the state of perfection, which is the vocation of each one of us, we no longer live in ourselves, but Christ lives in us; so that through our perfection Christ in his integrity and his indivisible unity, becomes in a sense each one of us, as he is completely in each host. The hosts are not part of his body. [23]

Brandt supports this notion:

They are necessary phases in the evolution of Man and will be overcome, neither by denial nor assertion, but by an understanding of their nature and purpose; not by setting aside the Laws of Nature, but by overcoming the lower with the higher. This is the Science of Transmutation by which men will become Divine. [24]

\section{Jung's Theory as Interpretation}

Johanna Brandt wrote The Millennium - A Prophetic Message to the Native Tribes of South Africa (1918) and The Paraclete or Coming World Mother (1939) during the Interwar period - (1918 - 1939). Simultaneously Weil writes; Waiting for God (Attente de Dieu) published in 1942 and Gravity and Grace (La Pesanteur et la grâce) first published 1947. Jung writes The Red Book or Liber Novus between 1913 and 1930, although only published in October 2009.

A manuscript considered as the key to Jung's oeuvre. Both verbally and visually Jung portrays his own mystical experience, his own descent into the collective unconscious where he encounters mediums, or spirit guides, one being 'Philemon' on his path towards transformation.[25] 
He coined the word synchronicity to describe what he called: "temporally coincident occurrences of acausal events." [26] Experiencing something that was first imagined. The manifestation of random incidents due to it's parallel nature of the physical and the non-physical. The word synchronization, to be in synch is defined as: 'to occur at the same time', 'to go on, move, operate, work, etc., at the same rate and exactly together'.

By drawing certain similarities while plasing Brandt's work in conversation with the Christian mystic, Simone Weil, a synchronicity between these experiences can be detected. Besides for the synchronistic nature of all these texts being written during the same period, within diverse religions, geographies and cultures, a synchronicity within Brandt's confessions of her personal mystical experience can be found within the unification of the paradox. This process of transformation towards individuation. A message that correlates with the works of Simone Weil. By interpreting these mystical experiences according to Jung's own interpretation of the 'mystical marriage', literature can serve as tool to shed a different light on these marginalized works of Brandt, works that were once ridiculed and derided.

Only the mystics bring religion to what is creative itself [27]

\section{References}

[1] J. Brandt, The Millennium - A Prophetic Message to the Native Tribes of South Africa, $3^{\text {rd }}$ ed., De Nationale Pers, Beperkt, Bloemfontein, 1918, pp 91.

[2] J. Grobler, The War Diary of Johanna Brandt, Protea Book House. Pretoria, 1918 pp. 9-20.

[3] C. G. Jung, Psychological Types, The collected Works of C. G. Jung, Vol. 6. Bollingen Series XX, Princeton University Press, Princeton, N. J. 1971, pp 741.

[4] C.G. Jung, Man and His Symbols, Ferguson Publishing, NY, 1964, pp 65.

[5] J. Grobler, The War Diary of Johanna Brandt, Protea Book House. Pretoria, 1918 pp. 9 - 20.

[6] J. M. Perrin and G. Thibon, Simone Weil as we knew her, Routledge, London, 1953.

[7] S. Weil, Waiting for God, reprint, Harper \& Row, NC, 1951, pp 68 - 69.

[8] J. Brandt, The Millennium - A Prophetic Message to the Native Tribes of South Africa, $3^{\text {rd }}$ ed., De Nationale Pers, Beperkt, Bloemfontein, 1918, pp 90.

[9] S. Weil, Waiting for God, reprint, Harper \& Row, NC, 1951, pp 69.

[10] Saint John of Te Cross, Dark night of the soul, Dover Publications, US, 2003.

[11] J. Campbell, The Hero's Journey: Joseph Campbell on His Life and Work (The Collected Works of Joseph Campbell) $3^{\text {rd }}$ ed, New World Library, California, 2014.

[12] J. Brandt, The Millennium - A Prophetic Message to the Native Tribes of South Africa, $3^{\text {rd }}$ ed., De Nationale Pers, Beperkt, Bloemfontein, 1918, pp 90.

[13] S. Weil, Waiting for God, reprint, Harper \& Row, NC, 1951, pp 7.

[14] S. Weil, Waiting for God, reprint, Harper \& Row, NC, 1951, pp 76.

[15] J. Brandt, The Millennium - A Prophetic Message to the Native Tribes of South Africa, $3^{\text {rd }}$ ed., De Nationale Pers, Beperkt, Bloemfontein, 1918, pp 90.

[16] S. Weil, Waiting for God, reprint, Harper \& Row, NC, 1951, pp 69.

[17] . Brandt, The Millennium - A Prophetic Message to the Native Tribes of South Africa, $3^{\text {rd }}$ ed., De Nationale Pers, Beperkt, Bloemfontein, 1918, pp 125.

[18] J. Brandt, The Millennium - A Prophetic Message to the Native Tribes of South Africa, $3^{\text {rd }}$ ed., De Nationale Pers, Beperkt, Bloemfontein, 1918, pp 90.

[19] A. Morgan, Die visioene van Johanna Brandt, Libanon Uitgewers, Mosselbaai, 1994.

[20] S. Weil, Waiting for God, reprint, Harper \& Row, NC, 1951, pp 69.

[21] J. Brandt, The Paraclete or Coming World Mother, privately published, 1936, pp 16. 
[22] S. Weil, Waiting for God, reprint, Harper \& Row, NC, 1951, pp 72.

[23] S. Weil, Waiting for God, reprint, Harper \& Row, NC, 1951, pp 80 -81.

[24] J. Brandt, The Paraclete or Coming World Mother, privately published, 1936, pp 33.

[25] C.G. Jung, The Red Book, Liber Novus, W. W. Norton \& Company; $1^{\text {st }}$ ed, NY, 2009.

[26] [Origanally given as a lecture, "tJber Synchronizitat" at the 1951 Eranos conference, Ascona, Switzerland, and published in the Eranos-Jahrbuch 1951 (Zurich, 1952). The present translation was published in Man and Time (Papers from the Ernaos Yearbooks, 3; NY and London, 1957).

[27] C.G. Jung, The Symbolic Life; Miscellaneous Writings, The collected Works of C.G. Jung, Vol. 6. Bollingen Series XX, Princeton University Press, Princeton, N.J. 1977, pp 540. 